\title{
Analysis of safety factors
}

\author{
Adrian Bralewski ${ }^{1, *}$ \\ ${ }^{1}$ The Main School of Fire Service, Civil Safety Faculty, 52/54 Słowackiego St., 01-629 Warsaw, \\ Poland
}

\begin{abstract}
An overview of the existing literature on safety factors proves that a number of variables conditioning the level of safety are extensive and very diverse. Many authors cite various determinants affecting the safety of society showing their relationship with strengthening immunity and reducing vulnerability. Accordingly, wide list of factors that can be used in research on their impact on safety is available. The author's earlier research identifies over 80 factors affecting the level of security. In the existing literature is not any scores which have attempted a comprehensive assessment of the suitability of factors in security. Due to the lack of research in this area, this article presents results of studies designed to assess the safety factors in the context of determining their hierarchy. The article presents the results of data collected in 2017 among The Main Schools of Fire Services students.
\end{abstract}

\section{Introduction and purpose of research}

An attempt to delineate the safety scale that allows its interpretation poses a challenge for researchers by years. All methods of risk assessment determine the risks in the form of numbers (in the case of quantitative methods), or descriptions (in the case of qualitative methods). Brings it to create diagrams, matrices and schemas, in which risk assessment takes a established scale (denoted as the quotient of impacts of the event and its probability). The risk is therefore a measure of security. The relationship between risk and security is inversely proportional in the strict sense. The lower risk, the greater the safety. Recognition of it allows to understand the security as the state of civilization and natural environment as specified by the level of its total risk [1]. Scientific studies indicate the risk, as a measure of threats assessment resulting from the possible adverse events. In addition, the risk is marked, as the layout of the three variables: probability of threats, the size of impacts and vulnerability to threats [2]. Vulnerability, in turn, can be consider with through the prism of two elements: resilience and sensitivity [3]. The resilience is affiliated with the control of the risk, with harm reduction capacity or with the ability to cope with them. The sensitivity of the affiliated with risk exposure [4]. In the methodology of the risk assessment for the purposes of crisis management system in Poland measure of vulnerability have become systemic and supplements barriers [3]. Systemic barriers are defined as systems whose task is to protect people from the threats, health protection and other protective systems. Supplement barriers in turn are defined as the sensitivity of the

\footnotetext{
* Corresponding author: abralewski@sgsp.edu.pl
} 
community on the threat in conjunction with resilience. In the case of systemic barriers risk assessment methodology authors identify two barriers relating to the efficiency of the State Fire Service and State Medical Service. Unspecified was, however, whether the other elements of the systems created by the State can be taken into account in the assessment of the systemic barriers. In the case of supplement barriers author evokes a number of indicators of vulnerability, which are reflected in the example the estimation of barriers. The author not points out, however, that the collection of recalled barriers is a closed collection.

The aim of the article is hierarchy the factors identified in previous studies, which may extend the number of systemic and supplements barriers used in Polish risk assessment methodology. In researches was used mutual comparisons methods based on Analysis Hierarchy Process. The list of factors, as well as the methods of their hierarchy are a test for the dissertation thesis of the author. For this reason, studies were carried out in two directions: on the one hand, efforts were made to collect proposals for changes in the methodology, on the other to make a preliminary analysis of received results in the test group.

\section{Factors determinants of security}

The first element of the test study was preliminary identification of factors based on a qualitative analysis of the literature sources. The process of identifying factors is an important piece of research, without which there would be a chance to go to further deliberations. It is also pointed out as a broad look at the factors approach to security in the international literature. During factors identification special attention was given to their subsequent usefulness to assess the level of safety and to build resistance to the crisis in a society. To this end, the selected factors pose to the universal base, which can be used at different levels of the administration of the country, in enterprises, scientific research, etc. In the following chapter the author focuses on the identification of factors, leaving aside at this stage of research, quantitative assessment of individual factors (e.g. saying that the age of the community affects the crisis situation is omitted numeric value people in the age group, which is more sensitive to the occurrence of a crisis situation).

In the literature can find factors that are closely correlated with the phases of crisis management. Part of the factors refers to the phase before the onset of threats and relates largely to issues related to the preparation to the crisis situation, others are related to the phase after the crisis and is reflected in the reconstruction after the crisis. The initial group of factors, used in polish risk assessment methodology, based on the categories of people and the tangible and intangible values [3]. Categorized and indicated more specifically factors have helped in the completion of the literature review, to compose a list of 80 factors (see Table). Listed in table 1 factors were divided into seven groups of influence:

- $\quad$ systemic factors (5 elements),

- $\quad$ area of operation services (6 elements),

- $\quad$ area of infrastructure (11 elements),

- life quality area (12 elements),

- group characteristic area (18 elements),

- individual features area (18 elements),

- region characteristic area (10 elements). 
Table 1. Factors determinants of security identified for the research.

Factor

(A) Group of systemic factors

\begin{tabular}{l|r}
\multicolumn{1}{c}{ Factor } & \multicolumn{1}{c}{ Source } \\
\hline \hline Legal norms & \multicolumn{1}{c}{ Parson et al. 2017-2021 [5], Martin 2014 [6] } \\
\hline Spatial planning & Parson et al. 2017-2021 [5] \\
\hline Political involvement & Parson et al. 2017-2021 [5], Martin 2014 [6], \\
& Cutter et al. 2008 [7] \\
\hline Well prepared plans for crisis management & Martin 2014 [6], Skomra et al. 2015 [3] \\
\hline Access to the service & Martin 2014 [6], Skomra et al. 2015 [3] \\
\hline
\end{tabular}

Source

\begin{tabular}{l|r}
\hline \multicolumn{2}{c}{ (B) Area of operation services } \\
\hline \hline Internal monitoring & Bolin 1993 [8] \\
\hline External monitoring & Bolin 1993 [8] \\
\hline Alarming & Bolin 1993 [8] \\
\hline Services Reliability & Skomra et al. 2015 [3] \\
\hline Material resources & Skomra et al. 2015 [3], Cutter et al. 2008 [7] \\
\hline The crime & Parson et al. 2017-2021 [5] \\
\hline
\end{tabular}

(C) Area of infrastructure

\begin{tabular}{l|r}
\hline $\begin{array}{l}\text { The presence of schools, kindergartens and } \\
\text { nurseries }\end{array}$ & Skomra et al. 2015 [3] \\
\hline Media & Cutter et al. 2003 [9] \\
\hline Critical infrastructure & Skomra et al. 2015 [3] \\
\hline Shopping areas & Skomra et al. 2015 [3] \\
\hline Air routes & Cutter et al. 2003 [9] \\
\hline Water routes & Cutter et al. 2003 [9] \\
\hline Sports facilities & Skomra et al. 2015 [3] \\
\hline Objects of cultural heritage & Cutter et al. 2003 [9] \\
\hline Religious objects & Skomra et al. 2015 [3] \\
\hline The presence of hospitals & Parson et al. 2017-2021 [5], Cutter et al. 2008 \\
& [7], Skomra et al. 2015 [3] \\
\hline Railway routes & Cutter et al. 2008 [7] \\
\hline \hline & (D) Life quality area \\
\hline Access to insurance & Martin 2014 [6], Cutter et al. 2003 [9] \\
\hline Access to your own car & Parson et al. 2017-2021 [5], Martin 2014 [6] \\
\hline Access to daily service & Martin 2014 [6] \\
\hline Access to drinking water & Cutter et al. 2003 [9] \\
\hline Access to medicines & Parson et al. 2017-2021 [5] \\
\hline Access to food & Martin 2014 [6] \\
\hline Access to hygienic measures & Martin 2014 [6] \\
\hline Access to health centers & Martin 2014 [6] \\
\hline Access to banking services & Martin 2014 [6] \\
\hline Access to shelters & Bolin 1993 [8] \\
\hline Access to media & Parson et al. 2017-2021 [5], Martin 2014 [6] \\
\hline Access to public transport & \\
\hline
\end{tabular}

Access to public transport

(E) Group characteristic area

\begin{tabular}{l|r}
\hline The composition of the family & Cutter et al. 2008 [7] \\
\hline The level of literacy & Parson et al. 2017-2021 [5] \\
\hline Cooperation & Parson et al. 2017-2021 [5] \\
\hline Social norms & Cutter et al. 2008 [7] \\
\hline Communication & Bolin 1993 [8] \\
\hline Household composition & Cutter et al. 2008 [7] \\
\hline Resident of the town / village & Parson et al. 2017-2021 [5], Martin 2014 [6], \\
\hline The activities of social organizations & Cutter et al. 2008 [7],Cutter et al. 2003 [9] \\
\hline Monthly per capita income & Parson et al. 2017-2021 [5] \\
\hline
\end{tabular}




\begin{tabular}{l|r}
\multicolumn{1}{c}{ Factor } & Source \\
\hline Ethical diversity & Martin 2014 [6] \\
\hline Working conditions & Martin 2014 [6], Cutter et al. 2008 [7] \\
\hline Protection of information & Parson et al. 2017-2021 [5] \\
\hline Relations with the community / neighbors & Cutter et al. 2008 [7] \\
\hline Social isolation & Martin 2014 [6] \\
\hline Command & Parson et al. 2017-2021 [5] \\
\hline Leadership & Parson et al. 2017-2021 [5] \\
\hline Control & Parson et al. 2017-2021 [5] \\
\hline Social resources & Parson et al. 2017-2021 [5] \\
\hline Age & Individual features area \\
\hline Knowledge & Parson et al. 2017-2021 [5], Martin 2014 \\
\hline Experience & [6],Cutter et al. 2003 [9], Cutter et al. 2008 [7] \\
\hline Sex & Parson et al. 2017-2021 [5] \\
\hline Race / skin color & Bolin 1993 [8] \\
\hline Awareness & Parson et al. 2017-2021 [5], Cutter et al. 2003 \\
\hline Education & [9], Cutter et al. 2008 [7] \\
\hline Practical experience & Martin 2014 [6], Parson et al. 2017-2021 [5], \\
\hline The degree of physical fitness & Cutter et al. 2008 [7] \\
\hline Religion & Bolin 1993 [8] \\
\hline Sexual orientation & Parson et al. 2017-2021 [5], Martin 2014 [6], \\
\hline Marital status & Cutter et al. 2008 [7] \\
\hline Have savings & Bolin 1993 [8] \\
\hline The social origin & Parson et al. 2017-2021 [5], Martin 2014 [6] \\
\hline Social status & Parson et al. 2017-2021 [5], Cutter et al. 2008 [7] \\
\hline Knowledge of foreign languages & Parson et al. 2017-2021 [5] \\
\hline Type of housing owned & Cutter et al. 2008 [7] Adger 2000 [10] \\
\hline Violence in the family & Martin 2014 [6], Skomra et al. 2015 [3] \\
\hline & Cutter et al. 2008 [7] \\
\hline
\end{tabular}

\begin{tabular}{l|r}
\hline \multicolumn{2}{|c}{ (G) Region charateristic area } \\
\hline The economic situation of the region & Cutter et al. 2008 [7] \\
\hline The frequency of the prevalence of threats & Martin 2014 [6], Parson et al. 2017-2021 [5] \\
\hline Developed logistics & Parson et al. 2017-2021 [5] \\
\hline Developed industry in the region & Skomra et al. 2015 [3] \\
\hline Density of population & Martin 2014 [6],Cutter et al. 2003 [9], Skomra et \\
& al. 2015 [3] \\
\hline Climate & Adger 2000 [10] \\
\hline Geographical location & Adger 2000 [10] \\
\hline Condition of roads in the region / type of road & Skomra et al. 2015 [3] \\
\hline $\begin{array}{l}\text { The variability of the population (dependent on } \\
\text { tourism / work outside the home) }\end{array}$ & Skomra et al. 2015 [3], Martin 2014 [6] \\
\hline Type of construction of houses / flats & Parson et al. 2017-2021 [5] \\
\hline
\end{tabular}

\section{Methodology}

The aim of the research is to get an ordered list of the factors listed in table 1 according to the impact to assess the safety. It is assumed that the hierarchy list will give the possibility of statistical analysis of the results for subsequent analysis and further research. In studies, the mutual comparison method is used, which is based on the Analytic Hierarchy Process [11]. AHP method checks in the situations when a group of persons is limited to a few- 
dozen people, and when the person carrying out the examination using this method are able to control the actions of people filling the questionnaire (for example, through willingness to answer questions at the evaluation time [12]. In the case of the test in question was necessary to make simplifications in the AHP method applied. This was dictated by:

Plenty of factors evaluated in the framework of one group (up to more than 20 factors) in relation to proposed in the literature for the maximum number of 9 elements in the comparator.

- A large sample of the research, which was getting results in a test group of students,

- The premise for the presentation of final results each filled questionnaire.

For this purpose, it was decided on the following changes to the terms of the original AHP method:

- Replace nine-point fundamental scale to the three-point scale, in which factors were judged by taking of the decision or of the factor A has a greater impact on a security, than factor B; If both factors were judged as equal then they receive the value of $\mathrm{A} / \mathrm{B}$.

- Changed the way to enter data into a matrix. No further assessing questions, which will be reflected in subsequent cells in the matrix. Shall fill the matrix values letter, which are a reflection of the following rated factors (A or B).

A thorough overview of the assumptions in the present pre-research, can be traced in the following example.

\section{EXAMPLE:}



Fig. 1. Matrix for factors assessment in systemic factors group.

It must be assumed that the preferences are reviewed, which of the identified factors is assessed as a factor of greater importance in the safety assessment. To this the matrix was developed to compare the factors in a given group, as in Fig. 1.

In cell with coordinates $\mathrm{AB}$ are compared factors "legal norms" and "spatial planning" (See Fig. 2). If a bigger impact on the level of security have a factor "legal norms" is in cell $\mathrm{AB}$ had to be enter the value "A", if the above is assessed factor "spatial planning" is in cell $\mathrm{AB}$ had to be enter the value of "B". If a respondent evaluates both factors as equally valuable in assessing the impact on the level of safety or there is no sentence which factor should get more value, in the cell AB should be put the value of A/B. Similar steps must be performed for evaluation of other factors, until the complete complement of the matrix. All evaluations shall be made in based on subjective assessments of respondents. 


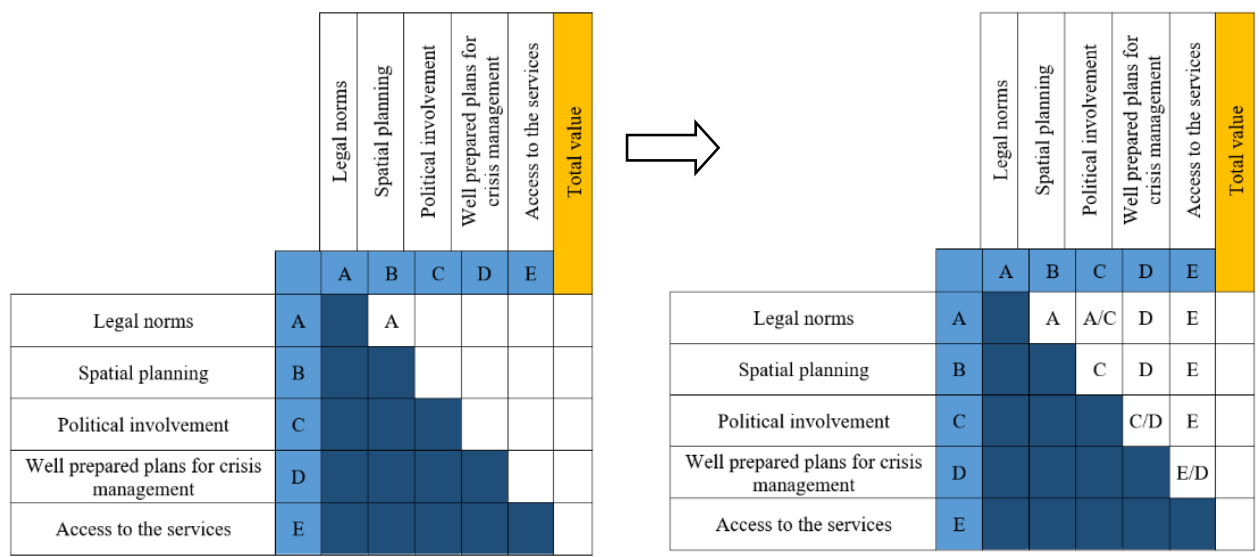

Fig. 2. Idea to asses matrix.

Then need to be sum all the cells with letters corresponding to the given factors (action performed on the stage of calculating the surveys). If the letter is in the cell is alone takes the value 1 if the value in the cell takes the form $A / B, C / D$, etc., the value for both letters (both factors) is counted as 0.5 . For example:

\section{The final value factor spatial planning $=\mathrm{A} / \mathrm{C}+\mathrm{C}+\mathrm{C} / \mathrm{D}=0.5+1+0.5=2$}

Similarly, for the other factors. The matrix takes the form as in Fig. 3. The following values were obtained from mutual comparisons methods: legal norms - 1,5; spatial planning - 0; political involvement - 2; well prepared plans for crisis management - 3; access to services $-3,5$. It follows that the factor of the highest importance in assessing the level of security is "access to services".



Fig. 3. A fully filled and counted matrix.

This example illustrates how an assessment should be made of the individual factors indicated in the matrix. To carry out research using the method indicated above, uses paper questionnaire, which collected and grouped all the identified factors in the form of matrix. For each group of factors was created a separate matrix. In addition, the matrix was created, in which respondents have to assess which of the groups should to the greatest extent affect the level of security. This was dictated by the purpose, enables in the article, creating a ranking list of all factors without division into groups 


\section{Results}

In order to be able to compare between the factors of the various groups, it was decided to apply the methods of comparison in relation to specific areas (groups) identified factors. This allows you to organize the factors on the one hand, in the framework of the group, as well as on the other parties within the meaning of the whole group in the evaluation system (Table 2.).

Table 2. Group value rating.

\begin{tabular}{|l|c|}
\hline \multicolumn{1}{|c|}{ Group name } & Group value rating \\
\hline Systemic factors & 0,1382 \\
\hline Area of operation services & 0,2462 \\
\hline Area of infrastructure & 0,1949 \\
\hline Life quality area & 0,1151 \\
\hline Group characteristic area & 0,1081 \\
\hline Individual features area & 0,0930 \\
\hline Region characteristic area & 0,1045 \\
\hline
\end{tabular}

Weight obtained in the framework of the particular groups are the basis to determine the weight of individual factors, according to the assumptions:

$$
V_{e}=V_{f} V_{g} \quad\left(\mathrm{~V}_{\mathrm{e}}, \mathrm{V}_{\mathrm{f}}, \mathrm{V}_{\mathrm{g}} \rightarrow 1\right)
$$

where:

$V_{e}$ - the final weight of the assessed factor,

$V_{f}$ - factor rating obtained in the group,

$V_{g}$ - the weight of the group, in which the assessed factor

The value $V_{f}$ and $V_{g}$ are based on the quotient of the sum of the ratings obtained by factors in subsequent questionnaires $\left(F_{s}\right)$ and the sum of the factors value in a given group $\left(G_{s}\right)$.

$$
V f=F s / G s
$$

The following table shows the ranking of the factors which, in the opinion of the responders, can most likely to have an impact on the assessment of the level of security (see column 5 and 7 in Table 3.). There is a dependency in the factor system that factors related to the operation of the services have been assessed as those that can determine the level of security to the greatest extent. may be justified by the greatest confidence that rescue services have and that the threats are associated mainly with the activities of the services. Next, it is worth paying attention to the fact that the group of systemic factors is high. Their choice may be justified by the awareness of the impact of the politicians on the general appearance of the State, including the rescue efforts. Big disasters are associated also with the help of State in the financial sphere. The third group of factors, according to the criterion of validity, is a group of infrastructure. Critical infrastructure protection activities carried out by the public authorities to increase awareness of the problem of downtime of these objects, and how big the economic effects this may cause. What's more, a group of infrastructure can be associated not so much with critical infrastructure as key objects of local infrastructure (KOLI). As KOLI should be understand the objects that meet a significant role in the context of services, which should provide the residents of the administrative unit (sewage treatment plants, water supply, electricity distribution and other similar objects). The aforementioned approach, as well as the table 3 provide can about setting priorities to strengthen the individual factors 
Table 3. Methods to sorting out the factors that affect the level of safety used in research.

\begin{tabular}{|c|c|c|c|c|c|c|}
\hline 1 & 2 & 3 & 4 & 5 & 6 & 7 \\
\hline Factor & $\begin{array}{c}\text { The } \\
\text { sum of } \\
\text { ratings } \\
F_{s}\end{array}$ & \begin{tabular}{|c|} 
The \\
sum of \\
group \\
ratings \\
$G_{s}$ \\
\end{tabular} & $\begin{array}{c}\text { Factor } \\
\text { rating } \\
\text { in } \\
\text { group } \\
V_{f}\end{array}$ & $\begin{array}{c}\text { Group } \\
\text { rating } \\
V_{g}\end{array}$ & $\begin{array}{c}\text { Factor } \\
\text { total } \\
\text { rating } \\
V_{e}\end{array}$ & $\begin{array}{c}\text { Hierarchy } \\
\text { ordinal } \\
\text { number }\end{array}$ \\
\hline Legal norms (A) & 38,0 & \multirow{5}{*}{283} & 0,1343 & \multirow{5}{*}{0,1382} & 0,018553584 & 14 \\
\hline Spatial planning (A) & 41,0 & & 0,1449 & & 0,020018341 & 12 \\
\hline Political involvement (A) & 33,0 & & 0,1166 & & 0,016112323 & 17 \\
\hline $\begin{array}{l}\text { Well prepared plans for crisis } \\
\text { management }(\mathrm{A})\end{array}$ & 82,5 & & 0,2915 & & 0,040280808 & 5 \\
\hline Access to the service (A) & 88,5 & & 0,3127 & & 0,043210321 & 4 \\
\hline Internal monitoring (B) & 477,0 & \multirow{6}{*}{419} & 0,1122 & \multirow{6}{*}{0,2462} & 0,027620701 & 8 \\
\hline External monitoring (B) & 45,0 & & 0,1074 & & 0,026445352 & 9 \\
\hline Alarming (B) & 97,5 & & 0,2327 & & 0,057298262 & 2 \\
\hline Services reliability (B) & 111,0 & & 0,2649 & & 0,065231867 & 1 \\
\hline Material resources (B) & 87,5 & & 0,2088 & & 0,051421517 & 3 \\
\hline The crime $(\mathrm{B})$ & 31,0 & & 0,0740 & & 0,018217909 & 15 \\
\hline $\begin{array}{l}\text { The presence of schools, } \\
\text { kindergartens and nurseries (C) }\end{array}$ & 87,0 & \multirow{11}{*}{1537,5} & 0,0566 & \multirow{11}{*}{0,1949} & 0,011026378 & 28 \\
\hline Media $(\mathrm{C})$ & 136,0 & & 0,0885 & & 0,017236636 & 16 \\
\hline Critical infrastructure (C) & 229,5 & & 0,1493 & & 0,029086824 & 6 \\
\hline Shopping areas (C) & 92,0 & & 0,0598 & & 0,011660078 & 25 \\
\hline Air routes $(\mathrm{C})$ & 169,0 & & 0,1099 & & 0,021419056 & 11 \\
\hline Water routes $(\mathrm{C})$ & 157,5 & & 0,1024 & & 0,019961546 & 13 \\
\hline Sports facilities (C) & 84,5 & & 0,0550 & & 0,010709528 & 30 \\
\hline Objects of cultural heritage (C) & 87,5 & & 0,0569 & & 0,011089748 & 26 \\
\hline Religious objects (C) & 82,5 & & 0,0537 & & 0,010456048 & 32 \\
\hline The presence of hospitals (C) & 227,5 & & 0,1480 & & 0,028833344 & 7 \\
\hline Railway routes $(\mathrm{C})$ & 184,5 & & 0,1200 & & 0,023383525 & 10 \\
\hline Access to insurance (D) & 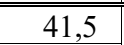 & \multirow{12}{*}{2216,5} & 0,0224 & \multirow{12}{*}{0,1151} & 0,002583706 & 77 \\
\hline Access to your own car (D) & 81,5 & & 0,0441 & & $\mid 0,005074026$ & 61 \\
\hline Access to daily service (D) & 122,0 & & 0,0660 & & 0,007595474 & 49 \\
\hline Access to drinking water (D) & 257,0 & & 0,1390 & & 0,016000303 & 19 \\
\hline Access to medicines (D) & 228,0 & & 0,1233 & & 0,014194821 & 21 \\
\hline Access to food (D) & 252,5 & & 0,1365 & & 0,015720142 & 20 \\
\hline Access to hygienic measures (D) & 178,0 & & 0,0962 & & 0,011081922 & 27 \\
\hline Access to health centers (D) & 215,0 & & 0,1162 & & 0,013385467 & 22 \\
\hline Access to banking services (D) & 77,5 & & 0,0419 & & 0,004824994 & 63 \\
\hline Access to shelters (D) & 210,5 & & 0,1138 & & 0,013105306 & 23 \\
\hline Access to media (D) & 89,5 & & 0,0484 & & 0,00557209 & 57 \\
\hline Access to public transport (D) & 96,5 & & 0,0522 & & 0,006007896 & 54 \\
\hline The composition of the family (E) & 231,5 & \multirow{11}{*}{4259,5} & 0,0543 & \multirow{11}{*}{0,1081} & 0,005872976 & 55 \\
\hline The level of literacy $(\mathrm{E})$ & 122,0 & & 0,0286 & & 0,003095046 & 75 \\
\hline Cooperation (E) & 316,0 & & 0,0742 & & 0,008016676 & 46 \\
\hline Social norms (E) & 178,0 & & 0,0418 & & 0,004515723 & 67 \\
\hline Communication (E) & 326,5 & & 0,0767 & & 0,008283053 & 43 \\
\hline Household composition (E) & 182,5 & & 0,0428 & & 0,004629884 & 65 \\
\hline Resident of the town / village (E) & 180,5 & & 0,0424 & & 0,004579146 & 66 \\
\hline $\begin{array}{l}\text { The activities of social } \\
\text { organizations (E) }\end{array}$ & 217,0 & & 0,0509 & & 0,005505123 & 58 \\
\hline Monthly per capita income (E) & 159,5 & & 0,0374 & & 0,004046392 & 69 \\
\hline Diversity (E) & 107,5 & & 0,0252 & & 0,002727192 & 76 \\
\hline Working conditions $(\mathrm{E})$ & 203,0 & & 0,0477 & & 0,005149953 & 60 \\
\hline
\end{tabular}




\begin{tabular}{|c|c|c|c|c|c|c|}
\hline 1 & 2 & 3 & 4 & 5 & 6 & 7 \\
\hline Protection of information (E) & 273,0 & & 0,0641 & & 0,006925799 & 51 \\
\hline $\begin{array}{l}\text { Relations with the community / } \\
\text { neighbors (E) }\end{array}$ & 205,0 & & 0,0481 & & 0,005200692 & 59 \\
\hline Social isolation (E) & 138,0 & & 0,0324 & & 0,003500954 & 73 \\
\hline Command (E) & 367,0 & & 0,0862 & & 0,009310507 & 36 \\
\hline Leadership (E) & 358,5 & & 0,0842 & & 0,009094869 & 38 \\
\hline Control (E) & 350,0 & & 0,0822 & & 0,008879230 & 39 \\
\hline Social resources $(\mathrm{E})$ & 344,0 & & 0,0808 & & 0,008727015 & 41 \\
\hline Age (F) & 221,5 & \multirow{18}{*}{4234} & 0,0523 & \multirow{18}{*}{0,0930} & 0,004865396 & 62 \\
\hline Knowledge (F) & 357,0 & & 0,0843 & & 0,007841745 & 47 \\
\hline Experience $(\mathrm{F})$ & 372,0 & & 0,0879 & & 0,008171230 & 44 \\
\hline $\operatorname{Sex}(F)$ & 164,5 & & 0,0389 & & 0,003613353 & 72 \\
\hline Race / skin color $(\mathrm{F})$ & 92,0 & & 0,0217 & & 0,002020842 & 79 \\
\hline Awareness (F) & 345,5 & & 0,0816 & & 0,007589140 & 50 \\
\hline Education (F) & 282,0 & & 0,0666 & & 0,006194320 & 53 \\
\hline Practical experience $(\mathrm{F})$ & 386,0 & & 0,0912 & & 0,008478750 & 42 \\
\hline The degree of physical fitness $(\mathrm{F})$ & 349,5 & & 0,0825 & & 0,007677003 & 48 \\
\hline Religion / religion $(\mathrm{F})$ & 117,0 & & 0,0276 & & 0,002569984 & 78 \\
\hline Sexual orientation $(\mathrm{F})$ & 89,0 & & 0,0210 & & 0,001954945 & 80 \\
\hline Marital status (F) & 143,5 & & 0,0339 & & 0,003152074 & 74 \\
\hline Have savings $(\mathrm{F})$ & 256,5 & & 0,0606 & & 0,005634195 & 56 \\
\hline The social $(\mathrm{F})$ & 165,5 & & 0,0391 & & 0,003635319 & 71 \\
\hline Social status (F) & 176,0 & & 0,0416 & & 0,003865958 & 70 \\
\hline $\begin{array}{l}\text { Knowledge of foreign languages } \\
\text { (F) }\end{array}$ & 313,0 & & 0,0739 & & 0,006875255 & 52 \\
\hline Type of housing owned (F) & 215,0 & & 0,0508 & & 0,004722620 & 64 \\
\hline Violence in the family (F) & 188,5 & & 0,0445 & & 0,004140529 & 68 \\
\hline $\begin{array}{l}\text { The economic situation of the } \\
\text { region }(\mathrm{G})\end{array}$ & 114,0 & \multirow{10}{*}{1245} & 0,0916 & \multirow{10}{*}{0,1045} & 0,009570256 & 34 \\
\hline $\begin{array}{l}\text { The frequency of the prevalence of } \\
\text { threats }(\mathrm{G})\end{array}$ & 191,5 & & 0,1538 & & 0,016076351 & 18 \\
\hline Developed logistics $(\mathrm{G})$ & 143,5 & & 0,1153 & & 0,012046770 & 24 \\
\hline $\begin{array}{l}\text { Developed industry in the region } \\
\text { (G) }\end{array}$ & 110,5 & & 0,0888 & & 0,009276433 & 37 \\
\hline Density of population $(\mathrm{G})$ & 129,5 & & 0,1040 & & 0,010871475 & 29 \\
\hline Climate $(\mathrm{G})$ & 96,5 & & 0,0775 & & 0,008101138 & 45 \\
\hline Geographical location $(\mathrm{G})$ & 111,5 & & 0,0896 & & 0,009360382 & 35 \\
\hline $\begin{array}{l}\text { Condition of roads in the region / } \\
\text { type of road }(G)\end{array}$ & 127,5 & & 0,1024 & & 0,010703576 & 31 \\
\hline $\begin{array}{l}\text { The variability of the population } \\
\text { (dependent on tourism / work } \\
\text { outside the home) }(\mathrm{G})\end{array}$ & 105,5 & & 0,0847 & & 0,008856684 & 40 \\
\hline $\begin{array}{l}\text { Type of construction of houses / } \\
\text { flats }(G)\end{array}$ & 115,0 & & 0,0924 & & 0,009654206 & 33 \\
\hline
\end{tabular}

\section{Conclusion}

History has shown that socially vulnerable populations are disproportionately impacted by disasters. These groups experience disproportionate suffering, particularly from public health and safety impacts such as injuries, death, and a decreased likelihood of recovery [6]. In this case importance is of gaining accurate and detailed assessment of the level of security, taking into account the characteristics of the society (its sensitivity and resistance to threats), and of obstacles resulting from existing infrastructure or efficiency of systems 
created by the State in charge of security. The list of identified factors, as well as the proposed method of assessing their suitability in assessing the level of security, may be useful in the implementation of this assumption. At this point, needs to be pay attention to several practical issues related to the method used:

- the time of completing the questionnaire by respondents is about 2 hours, which translates into the problem of its reliable completion,

- entering marks into matrix cells often resulted in a number of errors, especially in the case of matrices in which a large number of factors were evaluated,

- the time of summarizing the results by research is about 30 minutes per questionnaire, which in the case of large sample tests requires a lot of time for the technical side of the research,

- it would be a good idea to use a computer tool to assess the identified factors using the method indicated in the article.

Indicated in article approach is an evidence by the possibility to hierarchisation of factors that affect the level of safety in a large research sample. The results obtained determine how, and to what extent to utilize individual factors in the assessment of the level of security. On the other hand they are a valuable source of information for policy makers about what should be a start setting priorities for action to strengthening the individual factors. These results may be a signal to treat some factors as unnecessary in assessing the level of security too. In addition, the results provide possibility to further statistical analysis in order to obtain a deeper and more accurate conclusions. This is an important contribution to the understanding of social sensitivity in order to promote the building of social resilience.

The authors would like to acknowledge the Ministry of Higher Education for their financial support as part of statutory work under the number $\mathrm{S} / \mathrm{E}-422 / 9 / 16$. This article is the main aspects of the methodology used by the author in the prepared $\mathrm{PhD}$ dissertation "Influence systemic and supplement factors on the possibility of the emergence of crisis situations in the context of the functioning of the safety management system" under supervision of Prof Dariusz Majchrzak at War Studies University, Faculty of National Security (Warsaw).

\section{References}

1. J. Wolanin, Zarys teorii bezp. obywateli: ochrona ludności na czas pokoju (2005)

2. Red.G. Sobolewski, Źródła i przyczyny powstawania sytuacji kryzysowych, jako głównego zagrożenia bezpieczeństwa państwa (2013)

3. Red.W. Skomra, Metodyka oceny ryzyka na potrzeby systemu zarządzania kryzysowego RP (2015)

4. J. Lewis, Disaster Prev. Manag., 23/1 (2014)

5. M. Parson, S. Johal, a. o, Australian Natural Disaster Index

6. web page : https://www.bnhcrc.com.au/home

7. S.A. Martin, Int. J. Disast. Risk Re., 12, 53-80 (2014)

8. S.L. Cutter, L. Barnes, M. Berry, Ch.Burton, E. Evans, E. Tate, J. Webb, Community and Regional Resilience: Perspectives from Hazards, Disasters, and Emergency Management. CARRI Research Report 1 (2008)

9. R. Bolin, Household and Community Recovery After Earthquakes (1993)

10. S.L. Cutter, B.J. Boruff, W.L.Shirley, Soc. Sci. Quart., 84 (2003)

11. W. Adger, Prog. Hum. Geog., 24(3), 347-364 (2000)

12. A. Prusak, J. Strojny, P. Stefanow, HSS, 21, 179-192 (2014)

13. A. Prusak, P. Stefanów, AHP - analityczny proces hierarchiczny. Budowa i analiza modeli decyzyjnych krok po kroku (2014) 